Language and Empiricism 
Also by Siobhan Chapman

ACCENT IN CONTEXT

KEY IDEAS IN LINGUISTICS AND THE PHILOSOPHY OF LANGUAGE

(co-edited with Christopher Routledge)

KEY THINKERS IN LINGUISTICS AND THE PHILOSOPHY OF LANGUAGE (co-edited with Christopher Routledge)

PAUL GRICE, Philosopher and Linguist

PHILOSOPHY FOR LINGUISTS

THINKING ABOUT LANGUAGE: Theories of English 


\section{Language and Empiricism}

\section{After the Vienna Circle}

Siobhan Chapman

Senior Lecturer in English Language,

University of Liverpool 


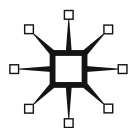

C Siobhan Chapman 2008

Softcover reprint of the hardcover 1st edition 2008 978-0-230-52476-7

All rights reserved. No reproduction, copy or transmission of this publication may be made without written permission.

No paragraph of this publication may be reproduced, copied or transmitted save with written permission or in accordance with the provisions of the Copyright, Designs and Patents Act 1988, or under the terms of any licence permitting limited copying issued by the Copyright Licensing Agency, 90 Tottenham Court Road, London W1T 4LP.

Any person who does any unauthorised act in relation to this publication may be liable to criminal prosecution and civil claims for damages.

The author has asserted her right to be identified as the author of this work in accordance with the Copyright, Designs and Patents Act 1988.

First published 2008 by

PALGRAVE MACMILLAN

Houndmills, Basingstoke, Hampshire RG21 6XS and

175 Fifth Avenue, New York, N.Y. 10010

Companies and representatives throughout the world

PALGRAVE MACMILLAN is the global academic imprint of the Palgrave Macmillan division of St. Martin's Press, LLC and of Palgrave Macmillan Ltd. Macmillan ${ }^{\circledR}$ is a registered trademark in the United States, United Kingdom and other countries. Palgrave is a registered trademark in the European Union and other countries.

ISBN 978-1-349-35718-5 ISBN 978-0-230-58303-0 (eBook)
DOI 10.1057/9780230583030

This book is printed on paper suitable for recycling and made from fully managed and sustained forest sources. Logging, pulping and manufacturing processes are expected to conform to the environmental regulations of the country of origin.

A catalogue record for this book is available from the British Library.

A catalog record for this book is available from the Library of Congress.

$\begin{array}{llllllllll}10 & 9 & 8 & 7 & 6 & 5 & 4 & 3 & 2 & 1\end{array}$

$\begin{array}{llllllllll}17 & 16 & 15 & 14 & 13 & 12 & 11 & 10 & 09 & 08\end{array}$ 


\section{Contents}

Introduction $\quad 1$

1 The Vienna Circle $\quad 7$

2 Falsification and Scientific Method 28

3 Holism 49

4 Ordinary Language Philosophy 68

5 Speech Acts and Implicatures 88

6 Oslo Philosophy 108

7 Interpretation and Preciseness 127

8 Empiricism in Linguistics 152

$\begin{array}{ll}\text { References } & 175\end{array}$

$\begin{array}{lr}\text { Index } & 186\end{array}$ 